\title{
MECHANISM OF ACTION OF NORADRENALINE ON SECRETION OF PROGESTERONE AND OXYTOCIN BY THE BOVINE CORPUS LUTEUM IN VITRO
}

\author{
Grażyna MiszKIEL and J. KoTwICA* \\ Division of Reproductive Endocrinology and Pathophysiology, \\ Institute of Animal Reproduction and Food Research of Polish Academy of Sciences, \\ 10-718 Olsztyn-Kortowo, Poland
}

(Received December 7, 1999; accepted October 30, 2000)

\begin{abstract}
The present studies were conducted: (1) to determine which $\beta$-adrenoceptor subtypes are involved in progesterone and oxytocin (OT) secretion, (2) to examine whether noradrenaline (NA) acts directly on the cytochrome P-450scc and $3 \beta$-hydroxysteroid dehydrogenase ( $3 \beta$-HSD), and (3) to study the effect of prostaglandin $\mathrm{F}_{2 \alpha}\left(\mathrm{PGF}_{2 \alpha}\right)$ on NA-stimulated steroidogenesis in luteal cells. The effect of NA on progesterone secretion from luteal slices of heifers on days 8-12 of the oestrous cycle was blocked by both atenolol ( $\beta_{1}$-antagonist) and ICI 118.551 hydrochloride ( $\beta_{2}$-antagonist). OT secretion was blocked only after treatment with ICI 118.551 hydrochloride $(\mathrm{P}<0.05)$. Dobutamine $\left(10^{-4}-10^{-6} \mathrm{M}\right)$, a selective $\beta_{1}$ agonist and salbutamol $\left(10^{-4}-10^{-6} \mathrm{M}\right)$, a selective $\beta_{2}$ agonist, both increased progesterone production $(\mathrm{P}<0.01)$ with an efficiency comparable to that produced by NA $(\mathrm{P}<0.01)$. The increase of OT content in luteal slices was observed only after treatment with salbutamol at the dose of $10^{-5} \mathrm{M}(\mathrm{P}<0.01)$. Dobutamine had no effect on OT production at any dose. A stimulatory effect of NA on cytochrome $\mathrm{P}-450 \mathrm{scc}$ activity $(\mathrm{P}<0.05)$ was demonstrated using 25-hydroxycholesterol as substrate. 3 $\beta$-HSD activity also increased following NA $(\mathrm{P}<0.01)$ or pregnenolone $(\mathrm{P}<0.05)$ and in tissue treated with pregnenolone together with NA $(\mathrm{P}<0.01)$. PGF decreased progesterone synthesis $(\mathrm{P}<0.05)$ and $3 \beta$-HSD activity $(\mathrm{P}<0.01)$ in tissue treated with NA. We conclude that NA stimulates progesterone secretion by luteal $\beta_{1}$ - and $\beta_{2}$-adrenoceptors, while OT secretion is probably mediated only via the $\beta_{2}$-receptor. NA also increases cytochrome P-450scc and 3 $\beta$-HSD activity. PGF inhibits the luteotropic effect of NA on the luteal tissue.
\end{abstract}

Key words: Cattle, corpus luteum, noradrenaline, progesterone, oxytocin

The stimulatory influence of catecholamines on secretion of progesterone and oxytocin (OT) from the corpus luteum (CL) of cattle has been found to be e xerted through $\beta$-receptors in both in vitro (Godkin et al., 1977) and in vivo studies (Kotwica et al., 1991; Skarżyński and Kotwica, 1993). $\beta$-adrenoceptors are of three

*Corresponding author; E-mail: janko@pan.olsztyn.pl; Fax: +48 (89) 524-0347 
subtypes, $\beta_{1}, \beta_{2}$ and $\beta_{3}$. The response of the female reproductive system to cat echolamines is modulated by the concentration of adrenoceptor sites on target cell surfaces. In the rat ovary receptors of the $\beta_{2}$ subtype mediate ovarian steroidogenic response (Adashi and Hsueh, 1981). In the rabbit and sow, $\beta_{1}$-receptors predominate in the ovary (Abramovitz et al., 1982; Perkins et al., 1986), while in the cow both $\beta_{1}$ - and $\beta_{2}$-receptors appear to be present (Battista and Condon, 1986; Pesta et al., 1994). The $\beta_{3}$-adrenoceptor was isolated at first in human adipocytes, however its role in reproductive tract is uncertain. Whereas beta-mimetics increase pre gnenolone production and stimulate $3 \beta$-HSD activity in rat granulosa cells (Jones et al., 1983), denervation of the ovary or chemical sympathectomy decreases $3 \beta$-HSD activity in rats CL (Burden and Lawrence, 1977).

Although the primary function of PGF is induction of luteal regression (McCracken et al., 1970; Hansel et al., 1973), several studies in the cow and other species have demonstrated that PGF increases progesterone production in in vitro experiments. While there is agreement on the luteolytic role of PGF ${ }_{2 \alpha}$ in vivo, studies examining its direct effect on luteal tissue gave inconclusive results. Steroidogenic cells occupied about $68 \%$ of the luteal tissue (O'Shea et al., 1989). Response of bovine small and large luteal cells is different after PGF ${ }_{2 \alpha}$ treatment. It was demonstrated that small luteal cells do respond to PGF $2 \alpha$ with an increase of inositol phosphates (Davis et al., 1988) and progesterone synthesis (Alila et al., 1988; Meidan et al., 1992), whereas in large luteal cells, PGF ${ }_{2 \alpha}$ slightly elevates (Meidan et al., 1992) or inhibits progesterone secretion in cells stimulated by LH or forskolin (Alila et al., 1988). This may be caused, in part, by variable homogeneity in enriched small and large luteal cell preparations, which contain other nonsteroidogenic cell types. For this reason we have used slices of CL rather then dispersed luteal cells to examine the role of $\mathrm{PGF}_{2 \alpha}$ in steroidogenesis. Bovine luteal cells and those of other species produce PGF (Milvae and Hansel, 1983; Pate, 1988), and therefore it is possible that PGF produced locally within the CL may affect luteal cells by paracrine/autocrine mechanisms thereby inte $\mathrm{r}$ fering effects of NA.

The aim of this study was to examine the effect of adrenergic agonists and antagonists on progesterone and OT production to determine which receptor subtypes are involved in the response of bovine luteal slices to NA. Furthermore, we wished to determine the influence of NA on cytochrome P-450scc and $3 \beta$ HSD activity and to investigate the poss ibility that PGF can affect NA-stimulated steroidogenesis in luteal cells. 


\section{Materials and methods}

\section{Corpora lutea collection and preparation of slices}

Bovine ovaries $(\mathrm{n}=35)$ were collected from a commercial slaug hterhouse within 15-20 min of death, immediately placed in flask with ice-cold medium (M-199; Sigma) put in crashed ice. Within 2 hours from ovaries collection co rpora lutea $(\mathrm{CL})$ were dissected from ovaries and cut with a tissue slicer (Natsume Seisakusho Co., Ltd; 250-400 $\mu \mathrm{m}$ ) in sterile conditions and washed 3 times b efore being incubated. The medium for collection of CL and for culture of slices was supplemented with $10 \%$ of calf serum (Sigma), penicillin $\left(10 \mathrm{IU} \mathrm{ml}^{-1}\right.$; Sigma), streptomycin (100 $\mathrm{g} \mathrm{ml}^{-1}$; Sigma), amphotericin ( $2 \mu \mathrm{g} \mathrm{m}{ }^{-1}$; Sigma $)$ and L-glutamine $\left(100 \mu \mathrm{g} \mathrm{ml}^{-1}\right.$; each suspended in $2 \mathrm{ml}$ of enriched M-199 were preincubated for $24 \mathrm{~h}$ at $37{ }^{\circ} \mathrm{C}$ in a humidified $5 \% \mathrm{CO}_{2}$ atmosphere. All experiments were performed on CL from days 8-12 of the cycle, as estimated on the basis of morphological observations published by Miyamoto et al. (2000). Data are pr esented as a rate of progesterone secretion into the medium $(\mathrm{ng} / \mathrm{ml}$ medium) and as a cumulative progesterone production in luteal slices ( $\mu \mathrm{g} / \mathrm{g}$ protein). Oxytocin content in luteal tissue was expressed as $\mathrm{ng} / \mathrm{g}$ tissue.

\section{Experiment 1}

The aim of experiment was to define the receptor subtype involved in the response of luteal cells to NA, by their secretion of OT and progesterone. Slices from bovine CL $(n=9)$ each in 4 replicates were pre-incubated for $24 \mathrm{~h}$ in medium. The medium was then replaced and the CL slices were incubated for $2 \mathrm{~h}$ with LH (100 ng/ml; gift from Dr A. F. Parlow - Pituitary Hormones \& Antisera Center, Torrance, CA) as a positive control, NA $\left(10^{-5} \mathrm{M}\right.$; Polfa, Poland $)$ and atenolol ( $\beta_{1}$-antagonist; Research Biochemical International, U.S.A.) or ICI118,551 hydrochloride ( $\beta_{2}$-antagonist; Research Biochemical International, U.S.A.) added $20 \mathrm{~min}$ prior to NA. In parallel experiment CL slices were treated for $2 \mathrm{~h}$ with dobutamine ( $\beta_{1}$-agonist; Sigma) or salbutamol ( $\beta_{2}$-agonist; Sigma). After the time of incubation the medium M-199 and slices were collected for progesterone and OT determination. Concentrations of added LH and NA were defined previously (Bogacki and Kotwica, 1999).

\section{Experiment 2}

To determine whether the NA influence on cytochrome P-450scc and $3 \beta$ HSD activity in CL ( $n=9$ and $n=8$, respectively), luteal slices after $24 \mathrm{~h}$ of preincubation were treated for $2 \mathrm{~h}$ with $\mathrm{LH}(100 \mathrm{ng} / \mathrm{ml})$, NA $\left(10^{-5} \mathrm{M}\right)$ and with pregnenolone $(10 \mu \mathrm{g} / \mathrm{ml}$; Sigma) alone or jointly with NA. In parallel experiment CL slices were treated for $3 \mathrm{~h}$ with 25 -hydroxycholesterol $(20 \mu \mathrm{g} / \mathrm{ml}$; Sigma) alone or together with NA. The 25 -hydroxycholesterol utilisation by luteal tissue is an 
indirect measure of cytochrome P-450scc activity, hence its activity was est imated by quantifying progesterone secretion into the medium. The $3 \beta$-HSD activity was measured in the slices.

\section{Experiment 3}

To examine the effect of PGF on NA-stimulated progesterone production, the luteal slices (from $9 \mathrm{CL}$ ) after $24 \mathrm{~h}$ of pre-incubation were incubated for $4 \mathrm{~h}$ with LH $(100 \mathrm{ng} / \mathrm{ml})$, NA $\left(10^{-5} \mathrm{M}\right), \mathrm{PGF}_{2 \alpha}(0.5 \mu \mathrm{g} / \mathrm{ml}$; Sigma $)$ or NA together with PGF. Progesterone concentration was measured in the medium and in two of four luteal slices, while $3 \beta$-HSD activity was measured in two other luteal slices of each treatment. The concentrations and the time of incubation with $\mathrm{PGF}_{2 \alpha}$ were established in preliminary studies.

\section{Luteal slices homogenisation}

Immediately following incubation luteal slices were frozen in liquid nitr ogen. Before assays frozen tissue was homogenised with a Vibratory Mill (Retsch $\mathrm{MM}-2)$. OT and progesterone were then from powdered tissue extracted as d escribed previously by Tsang et al. (1990). Recovery of OT and progesterone a veraged $90 \%$ and $85 \%$ respectively. Data were co rrected for procedural losses.

\section{Activity of $3 \beta-H S D$ determination}

The $3 \beta$-HSD enzyme assay was based on the procedure described by Murono and Payne (1979) in which the conversion of radioactive pregnenolone to progesterone was measured. Luteal slices were homogenised by Ultra-Turrax (T25-IKA) in $3 \mathrm{ml}$ of potassium phosphate buffer $(0.05 \mathrm{M})$ containing $1 \mathrm{mM}$ EDTA (pH 7.4). The assay was performed in glass tubes, which contained $50 \mu 1$ of $\left[{ }^{3} \mathrm{H}\right]$ pregnenolone $\left(\sim 2.86 \times 10^{5} \mathrm{dpm}\right.$; Amersham, sp. act. $\left.21.1 \mathrm{Ci} / \mathrm{mmol}\right)$ and $7.5 \mu \mathrm{l}$ of unlabeled pregnenolone $(5 \mathrm{nmol}), 20 \mu \mathrm{l}$ of assay buffer containing $10 \mathrm{nmol}$ NAD in $15 \%$ dimethyl sulphoxide and $80 \mu \mathrm{l}$ tissue homogenate. All assays were incubated for $20 \mathrm{~min}$. The reaction was stopped by placing the tubes in an ice bath. The samples were then extracted with $1 \mathrm{ml}$ of diethyl ether. Steroids were separated as described by Jones and Hsueh (1982).

\section{Hormone determinations}

Progesterone content in tissue and in medium was determined by RIA (Kotwica et al., 1990). The sensitivity was $15 \mathrm{pg} /$ tube and intra- and interassay variations were 8.4 and $16.2 \%$, respectively. The relationship between real (x) and determined (y) amounts of four different concentrations of progesterone added to the plasma samples is expressed by the linear regression equation $(y=0.99 x-0.14)$. 
OT concentration in luteal slices was determined by the method of Tsang et al. (1990). The hormone $(2 \mu \mathrm{g})$ was iodinated with $5 \mu \mathrm{Ci}$ of ${ }^{125} \mathrm{I}$ using chloramine T (Greenwood et al., 1963). The procedure of OT assay in medium was d escribed previously (Kotwica et al., 1996). The sensitivity was $3 \mathrm{pg} / \mathrm{ml}$. Intra- and interassay variations were 7.5 and $14.6 \%$, respectively. The accuracy of the pr ocedure is expressed by the linear regression equation $(y=0.99 x+0.14)$.

\section{Protein determination}

Protein assay was done by the burette Weichselbaum (1946) method using bovine albumin as standard. The sensitivity of the method was $0.5 \mathrm{mg} \mathrm{m}^{-1}$.

\section{Statistical analysis}

The secretion of progesterone and OT after antagonists treatment in E xperiment 1 was measured by comparison values with NA by means of ANOVA and Newman-Keuls as a post test. In all other experiments differences between mean ( \pm SEM) values were determined by one-way analysis of variance (Grap h$\mathrm{Pad})$. At least $\mathrm{P}<0.05$ was accepted as significant.

\section{Results}

\section{Experiment 1}

The viability of cells in luteal slices after $29 \mathrm{~h}$ of incubation was over $75 \%$ (trypan blue exclusion). The $\beta_{1}$-adrenoceptor antagonist atenolol $(0.5,2$ and $5 \mu \mathrm{g} / \mathrm{ml}$ ), significantly $(\mathrm{P}<0.05)$ decreased progesterone production after $2 \mathrm{~h}$ of incubation with NA (Fig. 1a) but it did not influence OT secretion at any dose (Fig. 1b). The $\beta_{2}$-adrenoceptor antagonist ICI 118.551 hydrochloride decreased $(\mathrm{P}<0.05)$ progesterone and OT secretion at all doses tested (Fig. 1a, b). Dob utamine $(1,10,100 \mu \mathrm{M})$, a selective $\beta_{1}$ agonist and salbutamol $(1,10,100 \mu \mathrm{M})$, a selective $\beta_{2}$ agonist, both increased progesterone production $(\mathrm{P}<0.01)$ relative to NA $(\mathrm{P}<0.01$; Fig. 2a). OT concentrations in medium was not changed. Ther efore the OT content in luteal slices shown; it was significantly higher compared to control only after treatment with salbutamol at $10 \mu \mathrm{M}(\mathrm{P}<0.01$; Fig. $2 b)$. Dobutamine had no effect on OT production at any dose (Fig. 2b).

\section{Experiment 2}

Treatment of slices with 25-hydroxycholesterol stimulated progesterone production $(\mathrm{P}<0.01$; Fig. 3) and NA amplified this effect of 25-hydroxycholesterol $(\mathrm{P}<0.05)$. Addition of pregnenolone increased progesterone production nearly twofold above the control level $(\mathrm{P}<0.01$; Fig. 4). Activity of $3 \beta$-HSD 
was also increased in luteal slices treated with NA $(\mathrm{P}<0.01)$ and pregnenolone $(\mathrm{P}<0.05)$. Incubation of slices with NA together with pregnenolone significantly elevated progesterone concentration $(\mathrm{P}<0.05)$ and $3 \beta$-HSD activity $(\mathrm{P}<0.01)$ when compared to the effect of NA and pregnenolone separately.
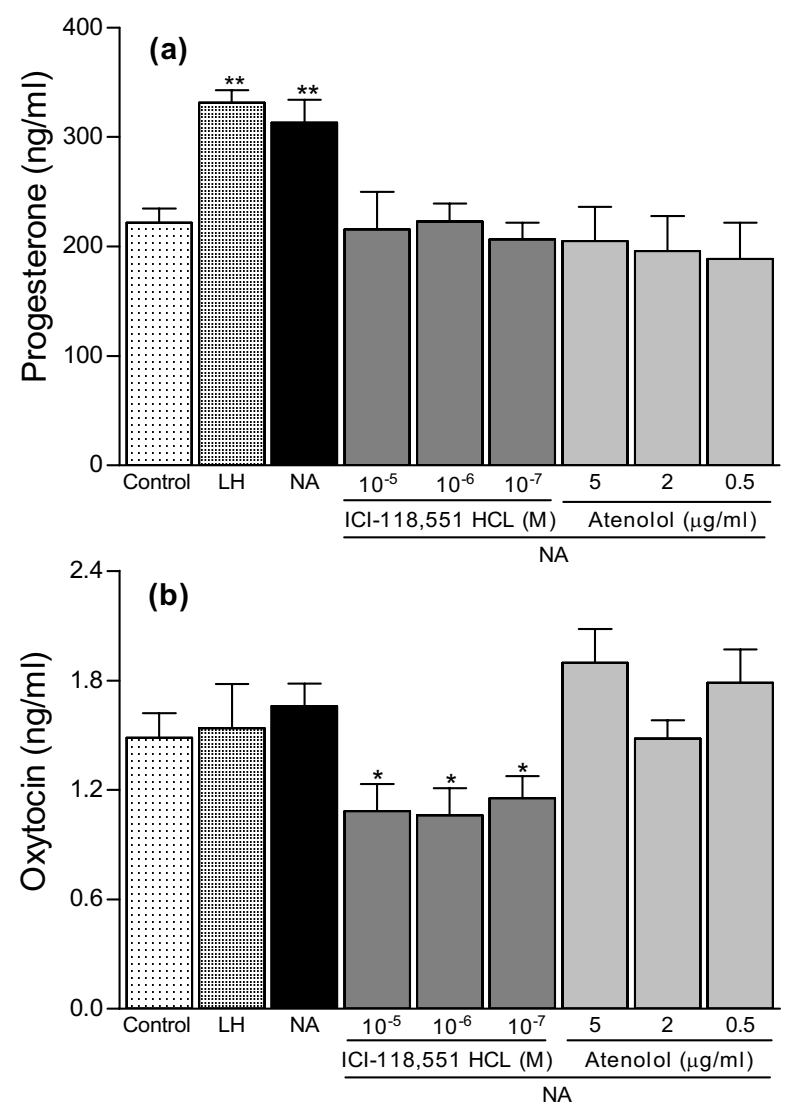

Fig. 1. Progesterone (a) and oxytocin (b) concentrations in medium after $2 \mathrm{~h}$ incubation of bovine corpus luteum slices from days 8-12 of the cycle with luteinising hormone ( $\mathrm{LH} ; 100 \mathrm{ng} / \mathrm{ml})$, noradrenaline $\left(\mathrm{NA} ; 10^{-5} \mathrm{M}\right)$ and NA together with atenolol $\left(\beta_{1}\right.$-adrenoceptor antagonist) or ICI-118.551 hydrochloride ( $\beta_{2}$-adrenoceptor antagonist). Results are means $( \pm$ SEM) of $9 \mathrm{CL}$. Different from NA $\left({ }^{*} \mathrm{P}<0.05\right)$ by ANOVA

\section{Experiment 3}

The concentration of progesterone in the medium was increased after $4 \mathrm{~h}$ of incubation of luteal slices with $\mathrm{PGF}_{2 \alpha}\left(\mathrm{P}<0.05\right.$; Fig. 5). $\mathrm{PGF}_{2 \alpha}$ did not alter the stimulatory effect on NA on progesterone secretion into the medium. Ho wever, $\mathrm{PGF}_{2 \alpha}$ suppressed the stimulatory effect of NA on tissue progesterone co ntent $(\mathrm{P}<0.05)$ and $3 \beta$-HSD activity $(\mathrm{P}<0.01$; Fig. 6$)$. 

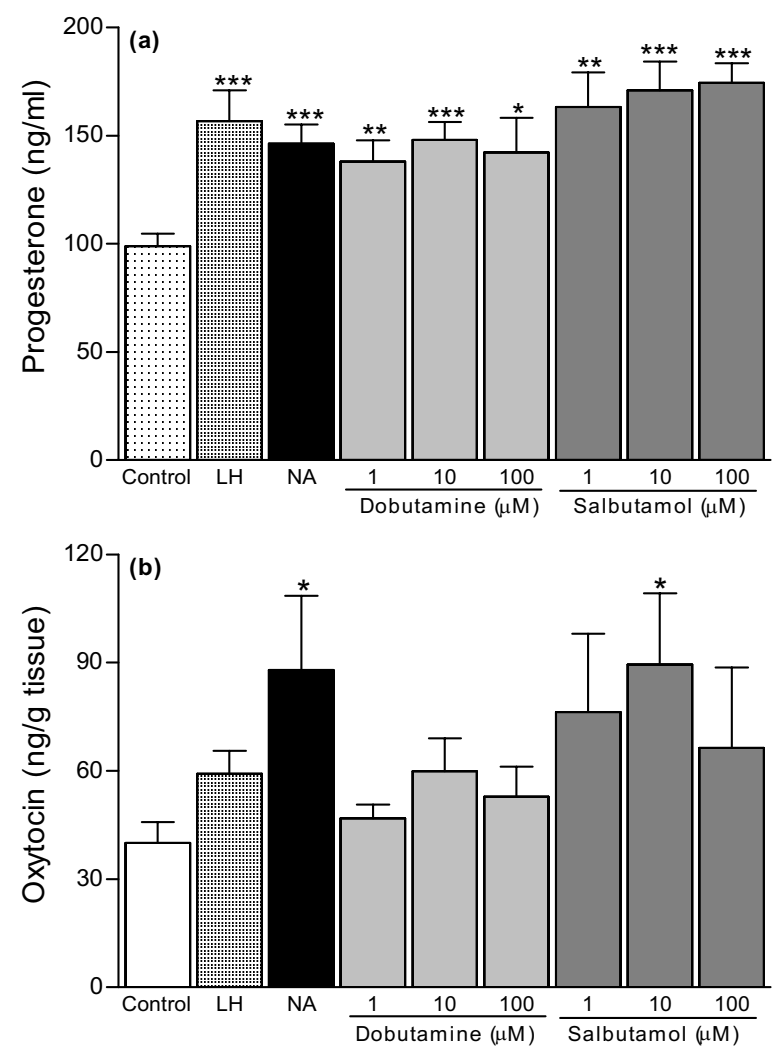

Fig. 2. Progesterone concentrations in medium (a) and oxytocin concentrations in tissue (b) after $2 \mathrm{~h}$ of incubation of bovine corpus luteum slices from days 8-12 of the cycle with luteinising hormone $(\mathrm{LH} ; 100 \mathrm{ng} / \mathrm{ml})$, noradrenaline $\left(\mathrm{NA} ; 10^{-5} \mathrm{M}\right)$ or dobutamine $\left(\beta_{1}\right.$-agonist $)$ and salbutamol $\left(\beta_{2^{-}}\right.$ antagonist). Results are means $( \pm \mathrm{SEM})$ of $8 \mathrm{CL}$. Different from control $\left({ }^{*} \mathrm{P}<0.05 ;{ }^{* *} \mathrm{P}<0.01\right.$; ${ }^{* * *} \mathrm{P}<0.001$ ) by ANOVA

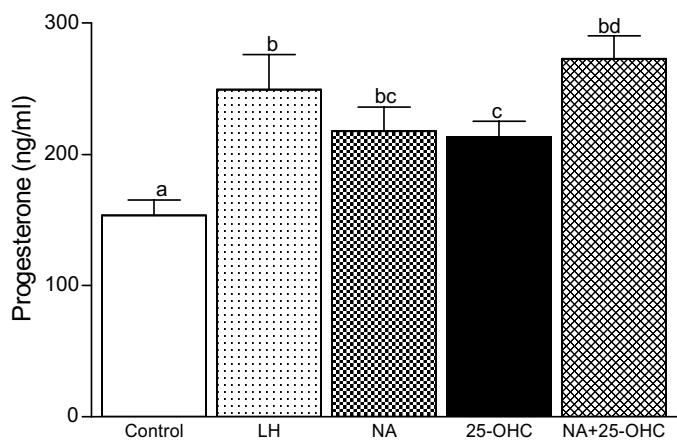

Fig. 3. Progesterone concentrations in medium after $3 \mathrm{~h}$ of incubation of bovine corpus luteum slices from days $8-12$ of the cycle with luteinising hormone $(\mathrm{LH} ; 100 \mathrm{ng} / \mathrm{ml})$, noradrenaline (NA; $\left.10^{-5} \mathrm{M}\right)$, 25-hydroxycholesterol (25-OHC; $\left.20 \mu \mathrm{g} / \mathrm{ml}\right)$ or NA together with $25-\mathrm{OHC}$. Results are means $( \pm$ SEM) of $9 \mathrm{CL}$. Bars with variable superscripts are different $(\mathrm{P}<0.05)$ 


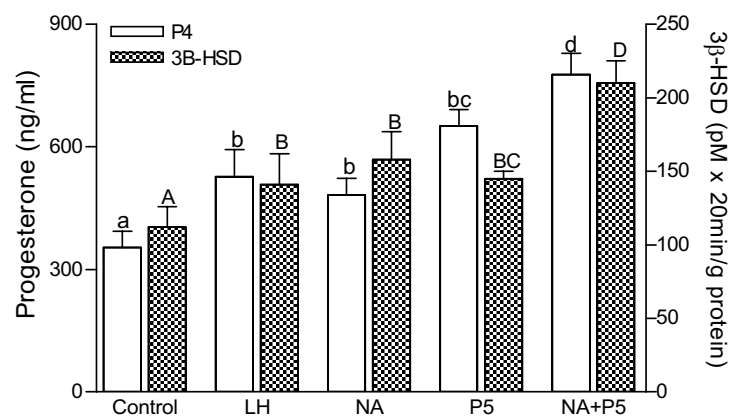

Fig. 4. Progesterone concentrations in medium and $3 \beta$-hydroxysteroid dehydrogenase (3 $\beta$-HSD) activity after $2 \mathrm{~h}$ incubation of bovine corpus luteum slices from days 8-12 of the cycle with luteinising hormone $(\mathrm{LH} ; 100 \mathrm{ng} / \mathrm{ml})$, noradrenaline $\left(\mathrm{NA} ; 10^{-5} \mathrm{M}\right)$, pregnenolone $(\mathrm{P} 5 ; 10 \mu \mathrm{g} / \mathrm{ml})$ and NA together with pregnenolone. Results are means $( \pm \mathrm{SEM})$ of $8 \mathrm{CL}$. Bars with variable superscripts are different $(\mathrm{P}<0.05)$

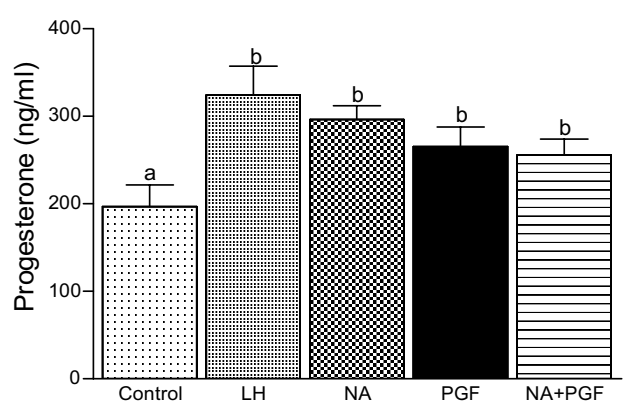

Fig. 5. Progesterone concentrations in medium after $4 \mathrm{~h}$ of incubation of bovine corpus luteum slices from days $8-12$ of the cycle with luteinising hormone $(\mathrm{LH} ; 100 \mathrm{ng} / \mathrm{ml})$, noradrenaline (NA; $10^{-5} \mathrm{M}$ ), prostaglandin $\mathrm{F}_{2 \alpha}\left(\mathrm{PGF}_{2 \alpha} ; 0.5 \mu \mathrm{g} / \mathrm{ml}\right)$ and NA together with $\mathrm{PGF}_{2 \alpha}$. Results are means $( \pm$ SEM $)$ of 9 CL. Bars with variable superscripts are different $(\mathrm{P}<0.05)$

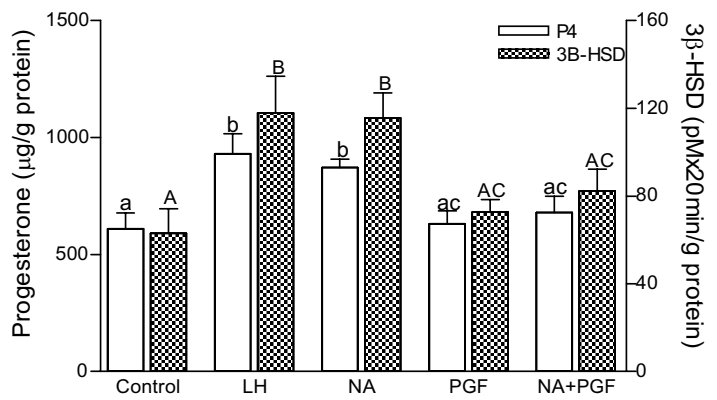

Fig. 6. Progesterone concentrations and $3 \beta$-hydroxysteroid dehydrogenase (3 $\beta$-HSD) activity in slices of bovine corpus luteum $(\mathrm{n}=9)$ from days $8-12$ of the cycle after $4 \mathrm{~h}$ of incubation with luteinising hormone $(\mathrm{LH} ; 100 \mathrm{ng} / \mathrm{ml})$, noradrenaline $\left(\mathrm{NA} ; 10^{-5} \mathrm{M}\right)$, prostaglandin $\mathrm{F}_{2 \alpha}$ $\left(\mathrm{PGF}_{2 \alpha} ; 0.5 \mu \mathrm{g} / \mathrm{ml}\right)$ and NA together with $\mathrm{PGF}_{2 \alpha}$. Results are means $( \pm \mathrm{SEM})$ of $9 \mathrm{CL}$. Bars with variable superscripts are different $(\mathrm{P}<0.05)$ 


\section{Discussion}

The present study showed that dobutamine ( $\beta_{1}$-receptor agonist) increased only progesterone secretion from bovine luteal slices, whereas salbutamol ( $\beta_{2}$ receptor agonist) stimulated both progesterone and oxytocin release. In agre ement with this, atenolol ( $\beta_{1}$-receptor antagonist) and ICI 118,551 hydrochloride ( $\beta_{2}$-receptor antagonist) significantly decreased progesterone production in luteal tissue. This suggests that both $\beta_{1}$ - and $\beta_{2}$-receptor subtypes are present in midluteal tissue, contributing to the overall CL response. These data correspond with those of Re et al. (1995) who showed that both $\beta_{1}$ - and $\beta_{2}$-adrenoceptor subtypes coexist in the ovary of adult cows. On the other hand ICI 118,551 hydrochloride diminished the stimulatory effect of NA on OT secretion. The results are consi stent with those of Luck and Münker (1991) who observed a pr edominance of $\beta_{2^{-}}$ receptor activity in OT secretion from cultured bovine granulosa cells. Although the presence of $\beta$-adrenoceptors in CL have been investigated in several species, the location of particular subtypes of $\beta$-receptors on large or small luteal cells has not been studied. More over, the data obtained are inconclusive. Isoprenaline, a $\beta$ agonist, increased progesterone production in large but not small ovine luteal cells in one study (Rodgers et al., 1985), but in another an opposite effect was observed in small and large cells (Niswender et al., 1985).

Since NA acting on CL has stimulated OT secretion which is only in large luteal cells (Fields et al., 1992) we assume that $\beta_{2}$-receptors are on large luteal cells. Differences between small and large luteal cells with respect to the amount of secreted progesterone (Weber et al., 1987) support this possibility. However, the presence of $\beta_{2}$-receptors on small cells cannot be excluded. Rapid commun ication between small and large cells cannot be ruled out, and hence $\beta_{2}$-receptors activation on large cells may activates the response of small cells, but this is a hypothesis which needs to be verified. Our results correspond with those by Payne and Cooke (1994) who showed that in the mid-luteal CL of goat $\beta_{2^{-}}$ receptors predominate in mediating the stimulatory effect of catecholamines. It is worthy noting that the proportion of $\beta_{1}$ - and $\beta_{2}$-receptors varies during the oestrous cycle in sheep (Payne and Cooke, 1994) and cattle (Battista and Condon, 1989). In contrast, studies in the sow have shown that $\beta_{1}$-receptors are more prevalent in early luteal tissue (Perkins et al., 1986) and the CL of rabbit also contains predominantly the $\beta_{1}$-receptor subtype (Abramowitz et al., 1982).

The first and rate-limiting step in progesterone biosynthesis is conversion of cholesterol to pregnenolone, which is catalysed in mitochondria by the cyt ochrome P-450 superfamily member, cholesterol side-chain cleavage enzyme. Tropic agents, such as LH and cAMP-mimetics, as well as protein synthesis i nhibitors, markedly affect steroidogenesis by cells utilising endogenous chole sterol as a substrate. Cholesterol side-chain cleavage enzyme is primarily co ntrolled by the availability of substrate. Thus steroidogenesis in the presence of 
25-hydroxycholesterol, which readily diffuses into the mitochondria, provides a measure of the maximal rate of hormone production (Toaff et al., 1982). The i ncrease in progesterone production in response to 25-hydroxycholesterol in the present study is consistent with results obtained in rat (Toaff et al., 1982), ha mster (Silavin and Strauss, 1983) and rabbit luteal cells (McLean et al., 1987). Moreover, the results of Experiment II indicate that the response of luteal tissue to 25-hydroxycholesterol is greater after NA treatment than in the presence of 25-hydroxycholesterol alone. Thus, it can be concluded that NA directly stim ulates the side-chain cleavage enzyme complex, although it may increase the availability of substrate to the enzyme rather than directly stimulates side-chain cleavage. Further investigation is necessary to elucidate the site of NA action. The second step in progesterone biosynthesis, conversion of pregnenolone to progesterone, is catalysed by the $3 \beta$-HSD. In Experiment II we showed that NA increased the activity of $3 \beta$-HSD. Thus, NA stimulates $\beta$-receptors in CL and affects progesterone synthesis by activating steroidogenic enzymes.

$\mathrm{PGF}_{2 \alpha}$ is a luteolysin in numerous species (Luck and Münker, 1991; Gadsby and Earnest, 1994). However, there are reports (Weston and Hixon, 1980; Speroff and Ramwell, 1970; Gadsby and Earnest, 1994) demonstrating a stimulatory action of PGF on progesterone production from luteal cells. The results of Experiment III showed that exposure of luteal slices to $\mathrm{PGF}_{2 \alpha}$ increased progesterone secretion into the incubation medium, whereas it did not influence progesterone synthesis as measured by $3 \beta$-HSD activity and progesterone content of the tissue. This lute otropic action of $\mathrm{PGF}_{2 \alpha}$ appears to be time- and dose-dependent, because its effect on CL slices in the present study was observed only after 4 hours of incubation. This is in contrast to the data of Girsh et al. (1994) who showed that PGF ${ }_{2 \alpha}$ increased progesterone production only in 2-4 day-old bovine CL slices, however, in CL slices obtained on days 6-12 of the oestrous cycle PGF $_{2 \alpha}$ did not alter cumulative progesterone production. It is not clear whether the difference is due to dose of $\mathrm{PGF}_{2 \alpha}$ used, incubation of luteal slices or length of time between slices preparation and treatment. Studies examining a direct effect of $\mathrm{PGF}_{2 \alpha}$ on luteal tissue showed inconclusive results. $\mathrm{PGF}_{2 \alpha}$ and cloprostenol increase or decrease progesterone s ecretion by dispersed luteal cells in ruminants (Speroff and Ramwell, 1970; Weston and Hixon, 1980; Fitz et al., 1984).

We have also demonstrated that PGF inhibits the stimulatory effect of NA on $3 \beta-H S D$ and progesterone production in CL from days 8-12 of the cycle. These findings are in agreement with those of Ahren et al. (1983) who showed that $\mathrm{PGF}_{2 \alpha}$ can inhibit the luteotropic effect of catecholamines in the rat CL. However, an opposite results were obtained in in vivo study, which showed that ovarian prostaglandins and NA independently regulate basal progesterone secr etion (Kotwica et al., 1994). There are reports that CL of several species, e.g. the pig, rat, sheep, rabbit, human and cattle (Milvae and Hansel, 1983; Pate, 1988) locally produces $\mathrm{PGF}_{2 \alpha}$. It was suggested that the ratio of luteotropic $\left(\mathrm{PGI}_{2}\right)$ to 
luteolytic $\left(\mathrm{PGF}_{2 \alpha}\right)$ prostaglandins $(\mathrm{PGs})$ produced by $\mathrm{CL}$ declines throughout the luteal phase in cattle (Milvae and Hansel, 1983). These authors also suggest that $\mathrm{PGF}_{2 \alpha}$ may antagonise the actions of $\mathrm{PGI}_{2}$ with respect to blood flow and progesterone synthesis. Therefore, an increasing production of luteolytic PGF ${ }_{2 \alpha}$ vs. luteotropic PGs in older CL might explain the decreased response of CL to cat echolamines. The observation made here that $\mathrm{PGF}_{2 \alpha}$ inhibits the luteotropic effect of NA on mid-cycle CL allows one to speculate that an inhibition of catechol amine influence on CL is part of the luteolytic mechanism. Whether this effect of $\mathrm{PGF}_{2 \alpha}$ can directly or indirectly disrupt the stimulatory effect of catecholamines on $\mathrm{CL}$ is not known yet.

\section{Acknowledgements}

We thank Dr S. Okrasa and Dr G. Kotwica (University of Agriculture and Technology, Olsztyn, Poland) for progesterone and oxytocin antiserum and Dr A. F. Parlow (Pituitary Hormones \& Antisera Center, Torrance, CA) for LH (AF9360B) donation. This study was supported by KBN grants (5 P06D 4010 and 5 P06D 049 14). We also thank Professor A. P. F. Flint (University of Nottingham) for critical review of manuscript and for English editing.

\section{References}

Abramovitz, J., Iyengar, R. and Birnbaumer, L. (1982): Guanine nucleotide and magnesium ion regulation of the interaction of gonadotropic and $\beta$-adrenergic receptors with their hormones: a comparative study using a single membrane system. Endocrinology 110, 336-342.

Adashi, E. Y. and Hsueh, A. J. W. (1981): Stimulation of $\beta_{2}$-adrenergic responsiveness by follicle stimulating hormone in rat granulosa cells in vitro and in vivo. Endocrinology 108, 2170-2176.

Ahren, K., Norjavaara, E., Rosberg, S. and Selstam, G. (1983): Prostaglandin F 2 $_{\alpha}$ inhibition of epinephrine stimulated cyclic AMP and progesterone production by rat corpora lutea of various ages. Prostaglandins 25, 839-851.

Alila, H. W., Dowd, J. P., Corradino, R. A., Harris, W. V. and Hansel, W. (1988): Control of progesterone production in small and large bovine luteal cells separated by flow cytometry. J. Reprod. Fertil. 83, 645-655.

Battista, P. J. and Condon, W. A. (1986): Serotonin-induced stimulation of progesterone production by cow luteal cells in vitro. J. Reprod. Fertil. 76, 231-238.

Bogacki, M. and Kotwica, J. (1999): Influence of noradrenaline on progesterone synthesis and post-translational processing of oxytocin synthesis in bovine corpus luteum. Theriogenology 52, 91-102.

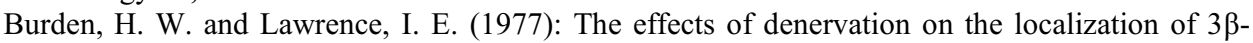
hydroxysteroid dehydrogenase activity in the rat ovary during pregnancy. Acta Anat. 97, 286-290.

Davis, J. S., Alila, H. W., West, L. A., Corradino, R. A. and Hansel, W. (1988): Acute effects of prostaglandin $F_{2 \alpha}$ on inositol phospholipid hydrolyses in the large and small cells of the bovine corpus luteum. Mol. Cell Endocrinol. 58, 43-50.

Fields, M. J., Barros, C. M., Watkins, W. B. and Fields, P. A. (1992): Characterization of large luteal cells and their secretory granules during the estrous cycle of the cow. Biol. Reprod. 46, 535-545. 
Fitz, T. A., Mock, E. J., Mayan, M. H. and Niswender, G. D. (1984): Interactions of prostaglandins with subpopulations of ovine luteal cells. II. Inhibitory effects of $\mathrm{PGF}_{2 \alpha}$ and protection by $\mathrm{PGE}_{2}$. Prostaglandins 28, 127-138.

Gadsby, J. E. and Earnest, K. L. (1994): Prostaglandin $\mathrm{F}_{2 \alpha}$ stimulates progesterone secretion by porcine luteal cells in vitro throughout the estrous cycle. Prostaglandins 48, 109-125.

Girsh, E., Greber, Y. and Meidan, R. (1994): Luteotrophic and luteolytic interactions between bovine small and large luteal-like cells and endothelial cells. Biol. Reprod. 52, 954-962.

Godkin, J. D., Black, D. L. and Duby, R. T. (1977): Stimulation of cyclic AMP and progesterone synthesis by $\mathrm{LH}, \mathrm{PGE}_{2}$ and isoproterenol in the bovine $\mathrm{CL}$ in vitro. Biol. Reprod. 17, 514-518.

Greenwood, F. C., Hunter, W. M. and Glover, J. S. (1963): The preparation of ${ }^{131}$ I-labelled human growth hormone of high specific radioactivity. Biochem. J. 89, 114-121.

Hansel, W., Concannon, P. and Lukaszewska, J. (1973): The corpora lutea of the large domestic animals. Biol. Reprod. 8, 222-245.

Jones, P. B. C. and Hsueh, A. J. W. (1982): Regulation of ovarian $3 \beta$-hydroxysteroid dehydrogenase activity by gonadotropin-releasing hormone and follicle-stimulating hormone in cultured rat granulosa cells. Endocrinology 110, 1663-1671.

Jones, P. B. C., Valk, Ch. A. and Hsueh, A. J. W. (1983): Regulation of progestin biosynthetic enzymes in cultured rat granulosa cells: effects of prolactin, $\beta_{2}$-adrenergic agonist, human chorionic gonadotropin and gonadotropin releasing hormone. Biol. Reprod. 29, 572-585.

Kotwica, J., Skarżyński, D., Bogacki, M. and Miszkiel, G. (1996): Influence of dopamine as noradrenaline precursor on the secretory function of the bovine corpus luteum using in vitro model. Br. J. Pharmacol. 118, 1669-1674.

Kotwica, J., Skarżyński, D. and Jaroszewski, J. (1990): The coccygeal artery as a route for the administration of drugs into the reproductive tract of cattle. Vet. Rec. 127, 38-40.

Kotwica, J., Skarżyński, D. and Jaroszewski, J. (1991): Involvement of $\beta$-adrenoceptors in the regulation of luteal function in cattle. Br. Vet. J. 147, 189-196.

Kotwica, J., Skarżyński, D., Jaroszewski, J. and Bogacki, M. (1994): Noradrenaline affects secretory function of corpus luteum independently on prostaglandins in conscious cattle. Prostaglandins 48, $1-10$.

Luck, M. R. and Münker, M. (1991): Beta adrenoceptors mediate the catecholamine-induced stimulation of oxytocin secretion from cultured bovine granulosa cells. Reprod. Fertil. Dev. 3, 715-723.

McCracken, J. A., Glew, M. E. and Scaramuzzi, R. J. (1970): Corpus luteum regression induced by prostaglandin $\mathrm{F}_{2 \alpha}$. J. Clin. Endocrinol. Metab. 30, 544-546.

McLean, M. P., Derdick, R. J. and Miller, J. B. (1987): The effect of human chorionic gonadotropin, dibutyryl cyclic adenosine 3',5'-monophosphate, prostaglandins and 25-hydroxycholesterol on acute progesterone secretion by dissociated rabbit luteal cells in vitro: Evidence for independent effects of human chorionic gonadotropin and lipoproteins. Biol. Reprod. 36, 854-863.

Meidan, R., Aberdam, E. and Aflalo, I. (1992): Steroidogenic enzyme content and progesterone induction by cyclic 3', 5'- monophosphate generating agents and prostaglandin $\mathrm{F}_{2 \alpha}$ in bovine theca and granulosa cells luteinized in vitro. Biol. Reprod. 46, 786-792.

Milvae, R. A. and Hansel, W. (1983): Prostacyclin, prostaglandin $F_{2 \alpha}$ and progesterone production by bovine luteal cells during the estrous cycle. Biol. Reprod. 29, 1063-1068.

Miyamoto, Y., Skarżyński, D. J. and Okuda, K. (2000): Is tumor necrosis factor $\alpha$ a trigger for the initiation of endometrial prostaglandin $\mathrm{F}_{2 \alpha}$ release at luteolysis in cattle. Biol. Reprod. 62, $1109-1115$.

Murono, E. P. and Payne, A. H. (1979): Testicular maturation in the rat. In vivo effect of gonadotropins on steroidogenic enzymes in the hypophysectomized immature rat. Biol. Reprod. 20, 911-919.

Niswender, G. D., Schwall, R. H., Fitz, T. A., Farin, C. E. and Sawyer, H. R. (1985): Regulation of luteal function in domestic ruminants: new concepts. Rec. Prog. Horm. Res. 41, 101-151. 
O’Shea, J. D., Rodgers, R. J. and D'Occhio, M. J. D. (1989): Cellular composition of the cyclic corpus luteum of the cow. J. Reprod. Fertil. 85, 483-487.

Pate, J. L. (1988): Regulation of prostaglandin synthesis by progesterone in the bovine corpus luteum. Prostaglandins 36, 303-315.

Payne, J. H. and Cooke, R. G. (1994): Effects of $\beta$-adrenergic agonist and other putative transmitters on progesterone production by dispersed ovine luteal cells. Anim. Reprod. Sci. 35, 91-97.

Perkins, S. N., Cronin, M. J. and Veldhius, J. D. (1986): Properties of $\beta$-adrenergic receptors on porcine corpora lutea and granulosa cells. Endocrinology 95, 998-1004.

Pesta, M., Muszyńska, A., Kucharski, J., Superata, J. and Kotwica, J. (1994): Beta-adrenergic receptors in corpora lutea from different stages of the estrous cycle in conscious and slaughtered cattle. Biol. Reprod. 24, 215-221.

Re, G., Badino, P., Novelli, A., Canese, M. G. and Girardi, G. (1995): Identification of $\beta$ adrenoceptor subtypes in bovine ovarian and myometrial cell membranes. Br. Vet. J. 151, $567-578$.

Rodgers, R. J., O’Shea, J. D. and Findlay, J. K. (1985): Do small and large luteal cells of the seep interact in the production of progesterone? J. Reprod. Fertil. 75, 85-94.

Silavin, S. L. and Strauss, J. F. (1983): Progesterone production by hamster granulosa and luteal cells during short term incubation. Effects of lipoproteins, compactin and 25-hydroxycholesterol. Biol. Reprod. 29, 1163-1171.

Skarżyński, D. and Kotwica, J. (1993): Mechanism of noradrenaline influence on the secretion of ovarian oxytocin and progesterone in conscious cattle. J. Reprod. Fertil. 97, 419-424.

Speroff, L. P. and Ramwell, W. (1970): Prostaglandin stimulation of in vitro progesterone synthesis. J. Clin. Endocrinol. Metab. 30, 345-350.

Toaff, M. E., Schelyer, H. and Strauss, J. F. (1982): Metabolism of 25-hydroxycholesterol by rat luteal mitochondria and dispersed cells. Endocrinology 111, 1785-1790.

Tsang, P. C. W., Walton, J. S. and Hansel, W. (1990): Oxytocin-specific RNA, oxytocin and progesterone concentrations in corpora lutea of heifers treated with oxytocin. J. Reprod. Fertil. 89, 77-84.

Weber, D. M., Fields, P. A., Romrell, L. J., Tumwasorn, S., Ball, B. A., Drost, M., Fields, M. J. (1987): Functional differences between small and large luteal cells of the late pregnant vs. nonpregnant cow. Biol. Reprod. 37, 685-697.

Weichselbaum, T. E. (1946): An accurate rapid method for the determination of proteins in small amounts of blood serum and plasma. Am. J. Clin. Path. Technical Sect. 10, 10.

Weston, P. G. and Hixon, J. E. (1980): Effects of in vivo prostaglandin $\mathrm{F}_{2 \alpha}$ administration on in vitro progesterone synthesis by bovine corpora lutea. Biol. Reprod. 22, 259-266. 